\title{
SYNTHESIS OF TRADITIONALITY AND DISTINCTIVENESS IN LITERARY HERITAGE
}

\section{Bekposhsha Rahimova}

Department of Uzbek Literature, Faculty of Philology, Urgench State University, Urgench, Uzbekistan.E-mail:

bekposhsharahimova726@gmail.com

\section{ABSTRACT}

The article interprets Sirojiddin Sayyid's work "The First Wonder" and "One Hundred Oh, Zahriddin Muhammad Babur" in the narrative aspect. In a unique form and style, the ideological and artistic essence peculiar to Navoi and Babur is interpreted from the point of view of the contemporary poet, while preserving the leading features of the spirit of general content, emphasizing the importance of universal views for today.

\section{Keywords:}

tradition, literary heritage, epos, form and style, skill, period and hero, symbolism,literary creativity, originality, symbolic image.

Article Received: 18 October 2020, Revised: 3 November 2020, Accepted: 24 December 2020

\section{Introduction}

Inheritance is one of the most pressing and complex issues that is being studied relatively actively in world literature. It is associated with creative talent, will,power, skill, worldview as a law of the development of artistic creativity. In this process, tradition emerges as an important factor in ensuring heirdom. Since "tradition" is the past achievements of the literature of a certain period, the creative assimilation, continuation and enrichment of its ideological and artistic riches for later times, this phenomenon occurs on the principle of uniqueness in repetition. In other words, succession continues through this principle [1].

Ideological-semantic, formal and other manifestations of tradition are the attributes of permanence, which change and improve due to the creative approach to reality, the level of thinking, the period, the characteristics of the situation, the need for socio-aesthetic needs. There are two aspects, which are quite obvious, to this: the creator's mastery of the heritage, his individual potential, his style, and his ability to express the spirit of the time, especially his use of words. Verily, "each epoch differs from the other epoch by its specific political-social-psychological mood, the work of art grows out of this epochmood and sometimes serves only its own period, sometimes due to its symbolism, multi-layered meaning it is consumed by other epochs"[2]. In this process, as symbolism, multi-layered meaning becomes a tradition, the elements of the existing work do not disappear completely, they change and are redesigned and renewed. The experience of world literature shows that in each genre a stable image, motif and means of imagery live on in national interpretations. Not even exactly or by completely replacing the plot and images to a new content, but by repeating them in new situations and conditions, new aspects are opened. Because "it is not always necessary to create a new image, opening up new features of other existing images is also a means of creating an image"[3].

Obviously, tradition is an aesthetic phenomenon of constant change, and "traditionalism is a peculiar feature and way of action of Eastern literature, which has both general similarity and repetition, as well as novelty and discovery. The goals and aspirations of the poets, their results and achievements are always very similar "(I. Hakkulov). This is an 
expression of the stages of assimilation of tradition, the relationship of internal and external types, and a necessary condition for the development of literary thinking is reflectted in literary creativity. While the literary creativity serves to enrich the tradition with new ideas and to provide originality in the ideological and artistic context, repetition serves as a factor that leads the creator to new achievements in previously tested forms.

The East, including Uzbek literature has rich potential in the expression of these features of the literary tradition - the role of the creator and the perfection of creativity, vitality, artistic talent, the way of thinking, the socio-aesthetic ideals and in the expression of the essence of literary creativity. Folklore and written literary traditions, which continue from the ancient past, are still an important source and base for works of art. Surely, in this process, the millennial traditions of our classical literature provides an inspiration and encouragement.

\section{Materials and Methods}

The centuries-old traditions of Uzbek classical poetry are based on the works of great artists and extraordinary talents. The works of Navoi, Fuzuli, Babur, Ogahi are still enjoyed by poets. Followers of their traditions are mainly manifested in two directions: 1) the creation of lyrical works in harmony with them, in particular, following their experince in ghazals, musammats and other subgenres; 2) creative mastery of experience in lyro-epic works (dastans - ornate forms of oral history from Central Asia), enrichment of content and form. First of all, interpretations of the "Khamsa" which is composed of five epic poems are considered here.

What is important is that there is almost no poet who has not tried himself in the first direction. In the second direction - to write about Navoi's epics,in particular "Khamsa", there were very few writers who fully understood and said a worthy word to the teacher (Navoi is meant here). In this regard, the aspirations of the Native Poets of Uzbekistan Omon Matjon and Sirojiddin Sayyid can be called a real synthesis of creative courage, tradition and literary creativity. In this respect, inheritance plays a significant role in classical epic poetry. They are mainly of two types - okhshatma (nazira) (okhshatma is a work written being influenced by a particular poem and writing a new work keeping its syllable weight, rhyme in literary science) and tazmin-dostons (tazmin is a work picking two lines from a certain poem as a base and writing a new work). For example, the dastans (epics) in Navoi's "Khamsa" and the work "Lison ut-Tayr" belong to the first form. Of particular interest in this regard is the tradition associated with the previous work: the evolution of the epic tadridj - the following conditional model in the epic - the "road map" provided integrity in succession:

1) "Mantiqut-tayr"-"The speech of Birds"(Farididdin Attor, XII century) $\rightarrow$

2) "Lisonut-tayr" - "The language of Birds" (Navoi, XV century) $\rightarrow$

\section{3) "The way of Birds" (O.Matjon, XX} century).

For these works, which are devoted to different periods and socio-philosophical issues, figurativeness and conditionality are a synchronous style, and the symbolism of the images of birds expresses a creative feature in artistic repetition.

\section{Discussion}

Omon Matjon's "The way of Birds" is the result of showing the continuity of literary heritage in twentieth-century Uzbek epics [4]. The skill of the poet is that he was able to synthesize the existing tradition of birds in folk art with the image of birds in Navoi's epic "Lison-ut tayr" ("The language of birds"). And he created an original work. While discussing high philosophical issues, the idea of glorifying goodness and nobility, man and life unites both works into one ideological point, the apprentice's interpretation reflects the spirit of the present, the dreams and aspirations of contemporaries. The images, means of expression and style of expression in Navoi's epic are renewed in the eyes of the successor poet, giving originality to the content and form. In this lyrical-epic work, the 
author's humanistic concept is generalized in the image of birds, emphasizing the continuity of the metaphorical tradition. Although this feature is rightly recognized in literary criticism, the idea that "O. Matjon follows the work of Navoi not in content, but in form" is controversial [5].

Sirojiddin Sayyid is one of the most strong representatives of modern Uzbek literature, the author of about twenty books of poetry. Over the past three years, 3 volumes of selected works and a collection of poems "Solim gulim"(My beautiful flower) were published (The first collection, "Рухим харитаси" (The Map of the Soul), was published in 1985). These works are very diverse in terms of theme, genre, image and expression, which gives the poet a reason to say that he has a unique high talent, mastering the secrets of classical and modern poetry. Genres and forms such as quatrain, ghazal, mukhammas, eight-line verse, dastan (epic) and turkum (series) are widely used in the poet's poetic treasure. According to Professor N. Rakhimjanov, they reflect "tragic truth, embodied in philosophical observation, journalistic encouragement, thoughtful psychological experiences in the artistic perception and expression of spiritual and moral, social issues" [6].

Taking a creative approach to classical literary experiments, the poet, who is seriously researched, evaluates his works as "trivial writings, in a sense modest summaries in his mind, another reflection on the heart, perhaps fragments of great unwritten poems." These "fragments" expanded in the following period and became important examples of lyrical-epic thinking. The epics "The Wonders of Khamsa" (The First Wonder) and "One Hundred Oh, Zahiriddin Muhammad Babur" are meant here. Although the poet called the first of them "poems," the predominance of ideas and lyro-epic character turned the work to a genre of epic. Its structural system is based not on a single traditional plot, a description of events, but on the poet's attitude to the views of the teacher (Navoi), the interpretation of the philosophical, socio- aesthetic essence of the general text, the natural harmony of teacher and student opinions in general.

The book "The First Wonder" consists of 51 poems and was written in the form of type of poetic art to Navoi's epic "Hayratul Abror"[7]. According to the classical tradition, new lines are added to the original text, including one line or a few verses from the works of other poets. This is skillfully expressed in "The First Wonder".

As we know, in Navoi's epic philosophical and educational views form the basis of the content and high human values are promoted. All elements of the work, as Professor N. Mallaev emphasized, "have a common compositional series with the ideological connection of the chapters, the origin and improvement of each other, and especially the image of the protagonist poet and thinker Navoi" [8]. This feature is also reflected in the epic of Sirojiddin Sayyid in terms of goals and objectives: the philosophical worldview was dominant in the descriptions of the issues raised, the traditional prefaces and maqolat (a small work within a work, an excerpt ; chapter) typical of the epics which are logically connected in short lines served to interpret, supplement, and delve deeper into the essence of a particular aspect of the content. The volume of the work consists of 910 verses, 150 of which are tazmin verses. They are addressed through a poem titled the topics in each chapter of the teacher's epic, which includes 1 hamd (praise), 8 nat (praise), 6 munojots (prayers), 35 maqolats. It is no coincidence that in the preface to "Endless Wonders", the author feels like an embarrassed reader and decides to express his admiration and the words of his heart in a poetic way, focusing on the most amazing lines in "Hayratul Abror" [8]. In "Words in the Heart", the poet was able to promote the eternal, exemplary values of the spiritual world of Navoi.

The work focuses on the description of maqolats that freely approach the structure of the epic, fully retaining the main content, in the style of the author stories and fables used in the epic of Navoi were omitted, but in the main text you can feel a hint of their conclusion. There are also 
chapters called "The Previous Wonder", "The Second Wonder ", "The Third Wonder " used by the teacher (S.Sayyid). The tazmin poems consist of 1 and 8-line verses, marked with numbers, and their interpretation contains the thoughts of the successor poet.

The creative approach to "Hayratul Abror" can be seen in other parts as well. In particular, in addition to maintaining the formal predominance of masnavi, which is characteristic of traditional epics, he also uses quatrains, mukhammas, and ghazals. As a result there is a variety of rhymes, radifs, bahr and other elements. The author also describes and generalizes the content of the largescale introduction, which is praised by Nizami, Dehlavi, Jami, in his concise independent poems such as "Lion's Paw", "Five Mountains", "Two Different Worlds", "Khamsa. Farhod and Navoi", "The meaning of a breath", "Make a friend", and starts with a comment: "There is no meaning from not only a friend, but also a foe. Make me a friend with "Hayratul Abror"”.

In Chapter XII of the original work, the poet takes the verse

"It is his duty to dig a mountain of pain,

The mountain is the weapon of his method of poetry",

which praises the great writers of "Khamsa" and uses this verse as a tazmin and calls this work "The Fifth Nat" with a title "On the Nazm(Poetry) Mountain" and connects his views on Navoi's thoughts:

Someone is looking for minerals, someone sweeps snow

The sky over the mountain is also endless and blue.

The poets smile from the high peaks

Like Nizami, Dehlavi, Jami, Navoi (49).

It should be noted that human purity, asornment, perfection, and the idea of the struggle for the depth of the meaning of life is embodied in every piece of poetry that the follower (S.Sayyid) calls munajat, hayrat (wonder), maqolat.
In the work, Navoi's interpretations are chosen according to the nature of a particular topic, often at the beginning of the pages in place of an epigraph. For example, a series of munajats and hayrats are quoted from the praises of man, with the emphasis on the following verse:

"Even if you (God is meant here) have created all wonders

The goal of their creation is Man (25).

The disciple (S.Sayyid) further clarifies the aspects of meaning in the hidden layer of this wise thought with his 56-line masnavi, emphasizing the spiritual essence and sublimeness of man by emphasizing the four elements of his appearance, using affirmations, invitations, and utterances according to the type of expression. Poems dedicated to the interpretation of verses provide the reader with two functions: first, to draw the reader's attention to the original meaning of Navoi's views, and second, to add to that meaning the poet's unique approach, findings, and expand the scope of the whole imagination.

It is known that the 6th maqolat of Hayrat al-Abrar is devoted to the issues of etiquette among people[10]. The content of the 119 verses that make it up is generalized in the following verses:

"Whoever is older needs service The younger one needs mercy "( $p$.

161)

Sayyid took the verse as a tazmin and wrote a poem consisting of 7 quatrains entitled "The Elder and the Younger " corresponding to its meaning. One of the peculiarities of the poem is that Navoi's verse is presented as a refrain in every 3rd and 4th lines of each quatrain, and rhyming words like "respect", "honor", "thanks", "encouragement", "invitation", "conversation", "generosity" are used before the last repeated word "necessary", by which consistent melody is provided, 1st and 2nd rhyming lines of the verse are embedded in the content ("Advice is in reality a life, one side is the name, the other one is the memory" and so on). 
The author's disciple ability is also seen in his creative approach to other maqolats. In this regard, the poem "Benefit" is especially characteristic. The poem consists of only two quatrains. But it is the essence of Navoi's thoughts in the thirteenth maqolat about the need for a person to be selfless, self-interested, useful in deeds or words and are reflected in the following verses:

If benefit is for the people, it is not wasted

Know that, this benefit is a bridge for you. As this verse comes in place of the tazmin, its content takes place as a continuation of the master poet's views, a deeply felt expression of purpose. The following quatrains are similar to certain aspects of Navoi's wise subjective beliefs:

Nothing in the universe goes without a trace, If you give a twig, it is a light to your eyes.

If you put a twig on water, undoubtedly

One day become a bridge will come back to yourself.

Also, in the commentary of other articles, the poet thinks based on the teacher's intention, the ideal, and does not forget the spirit of the new era. In general, inspired by Navoi's multifaceted philosophical and educational lessons, our contemporary poet, who is able to be his colleague and constant follower, with his work convincingly demonstrates the inseparable nature of creativity in the literary heritage, the centuries-old improvement and renewal, and boldly pursues wisdom in his research.

Another example of the connection between the process, tradition and innovation of literary creation in action is the epic "One Hundred oh, Zahiriddin Muhammad Babur" by Sirojiddin Sayyid [11]. It embodies many aspects of the tazmin phenomenon in traditional lyrical and lyro-epic works. In addition to all types of poetic forms, tazmin also refers to prose fragments, which form the basis of the general text. Regarding the style of narration of the poem, which is devoted to the interpretation of the life and work of the poet, king, historian and thinker Babur, the author says: "Sometimes from the language of Hazrat Babur, sometimes from myself, sometimes in the form of poetry, sometimes in the form of ghazals, sometimes in the form of rubai I tried to write my goal"[12]. Also, comparing the work with the building, Professor N. Jabborov rightly argues that the "Baburnoma" and the most delicate points in Babur's poetry are based on memories, thoughts and experiences, verses and rubais, "One Hundred oh, Zahiriddin Muhammad Babur" is the first embellished epic, it has a special literary and aesthetic value "[13].

In the structure of the epic, a consistent line of thought in the form of "tazmin-iqtibossharx"(quote-commentary) is followed, in the first pages of which he gives the hasbu hol motive and description of "Boburnoma": "Let everyone read this story, I did see many pain, trouble, grief." . Each of the melodic words in this description, such as "Qadrnoma", "Taqdirnoma", "Jabrnoma", "Harbiynoma", "Kabirnoma" refers to the nature of the events in Babur's activity and works, as well as he begins to interpret the epic like "epic of my heart", "Shahnama of the Turks".

The author approaches the quotations according to the volume, content, and purpose of the verse and prose writings. Naturally, when the tazmin presenting ghazal, the rubai consists of some lines or verses, it gives more opportunity to the passages of epic events. In some cases, it may be observed that both of them can occur together.

In "Boburnoma", the princes, historical figures, landscapes and events depict Babur, on the one hand, as the ruler of his time, an eyewitness, and, on the other hand, as the narrator, which is reflected in every interpretation of the epic and the poems are titled accordingly. In the poem "Andijan is visible" Babur's memory of his father is published as follows: "After one or two days I set off Axsi and Andijon through Kondorlik dobon (pass). When I reached Aksy, I visited my father's grave". The author focuses on the description of Andijan and Samarkand, as the poet gives a different place in the poem to the description of his father Umarshaikh. The poem consists of 8 verses, in which Babur's memories, 
especially about Samarkand, and his thoughts about his life come to the fore:

Farewell Samarkand, when I think of your skies,

From every cloud I see a sakhibkiran (a great leader)

Like a yellowed leaf I have left this land

I can see two worlds like fallen leaves (172).

At the end of the poem, the verse "My parents stayed in the homeland as a pile of soil" is a convincing sign of the seperation in Babur's heart.

Quotations from "Boburnoma" mainly reflect Babur's assessment of countries, cities, fortresses, addresses, and the characteristics of the period and environment. Lots of tazmin poems to them is a part of this relationship, a continuation of which is in harmony with the author's opinion. In particular, Sayyid's 9-verse ghazal "Sultan Hussein's time" is quoted as follows (227-228). Babur writes: "The time of Sultan Husayn Mirza was a wonderful time, the people of virtue and uniqueness conquered Khorasan, the city of Herat. Whoever had a job, had the same sincerity and ambition, which they will do it until the level of perfection"(in the part of the events of 15051506). The meanings underlying this brief description are found in each verse of the ghazal. In particular, the verse "The time of Sultan Hussein was a good time, the people survived in the development of science and profession" summarizes the whole content of the ghazal. "The prosperity of Herat, the joyful life of the sympathetic people, the mutual awareness of the king and the people, the spread of enlightenment and love to the world" are described in the following verses, and the literary intention is clarified by the final conclusion verse "On the one hand there was the world, on the other hand there was Herat itself"

In the attitude of the successor poet to the original text, the level of understanding of each other, the understanding of the original essence is an important condition. A clear example of this is often found in the epic. S. Sayyid is able to effectively explain the thoughts, state of Babur in different situations, providing harmony in the interpretation. The proof of this can be following verse written under the influence of the excerpt from "Boburnoma" "there is no land to go, there is no place to stay. I was reported to leave Kabul for Hindustan, and the amount of their badness increased, their goodness turned into badness" (from the events of 1507-1508):

The end of my poetry turned into a sultanate,

My sultanship turned into a lifetime of confusion.

One evil of yours, Oh world, was ten evil for me

Even the good turned into evil in the end (233).

At the heart of these seemingly simple messages is a deep meaning: on the one hand, it reflects the conflicting processes in Babur's destiny, on the other hand, his philosophical views on the world, fate, and the state of the hero's psyche in an aesthetic context.

Babur's condemnation of unfaithful land, the betrayal of his enemies, and his hatred of violence are also found in the mukhammas written for ghazals. Sayyid writes such five-line verses compatible with Babur's ghazals on romantic and socio-political themes and strengthens the poetic meaning. In particular, his mukhammas entitled "The ones who have forgotton us" is one of them. Impressing by Babur's this verse:

It is necessary to behave via soul, with pleasure,

We must forget the forgetful,

he wrote a five-fold mukhammas[14]. In this case, he expands the scope of the main idea of the "soul", being successor with the teacher (Babur), and adorns each verse with novel comments. In particular, the words of wisdom like "it is necessary to wait for the right time of everything, and so to swallow the honey in time" (item 1), "to dry the sapling of grief" (item 2), "to lighten the heart with the fire of love" (item 3), to solace oneself with pleasure "(Paragraph 4), " the house 
of grief must be set on fire "(paragraph 5) are consistent with the original text both in content and in form. It is true that S. Sayyid did not fully preserve the syllable weight, rhyme and images in ghazals, ruba' is (quatrains) and mukhammas. But his approach is based on creative originality, without violating the classical rule of thumb.

\section{Conclusion}

Based on the above considerations, the following conclusions can be drawn:

- Development of artistic creativity is a living process, based on certain features. One of these is that the literature of each period is connected with the artistic thinking of the past and is renewed as its successor and logical continuation;

- The aspects of the system of literary succession are expressed in terms and concepts, such as uniqueness, tradition, experience, literary creativity, creative approach and tazmins in repetition.

- Tazmin is also a test of art and skill. S. Sayyid created remarkable examples of it in his epics "The First Wonder" and "One Hundred Oh, Zahiriddin Mukhammad Babur". Each of them reflects the uniqueness at the heart of tradition. Thus, the philosophical and educational character of the first epic is the original work, which corresponds to the essence of the original "Hayratul abror". The style of socio-aesthetic direction prevails in it.

"One Hundred oh, Zahiriddin Muhammad Babur" is characterized by a wide range of poetic and prose quotations, and is a leader of lyrical-epic interpretation due to the influence of historical events, Babur's adventures, scenes of life.

- In both works, the author was able to fully embody their historical and literary characters by following the great figures such as Navoi and Bobur. In general, tazmin as an important form of continuous literary succession is the basis of cooperation of poets of different periods as well as a poetic conversation.

\section{References:}

[1] Bushmin A.S. On repeatability in the process of literature development // A. Bushmin, Science of Literature, Moscow, 1980, pp. 184-201. Barabash, Yu. Ya. repeated uniqueness // Modern issues of literary criticism and linguistics. Moscow, 1974. pp. 65-93.

[2] Hamdamov U. Reflection of the spirit of the time in poetry // Uzbek language and literature. 2001. p.20.

[3] Lorka G. Selected works in 2 volumes. Volume 1.M. 1986. p. 398-399.

[4] Omon Matjon. The light of faith. Tashkent. G. Gulom Publishing House of Literature and Art, 1995. p. 381.

[5] Panaeva O. The concept of history in modern Uzbek poetry (through the example of the work of Omon Matjon). Ph.D. dissertation abstract. Tashkent.2005. p.21.

[6] Rahimjonov N. Uzbek poetry of the independence period. Tashkent. Fan.2007. p.164.

[7] Sirojiddin Sayyid. "Wonder of Khamsa" "The First Wonder". Tashkent. "Sharq". 2016. p.110.

[8] Mallaev N. History of Uzbek literature. Book I. Tashkent. "Teacher". 1976. p. 424.

[9] Sirojiddin Sayyid. "Wonder of Khamsa" "The First Wonder". Tashkent. "Sharq" .2016. p. 9. (Subsequent examples are taken from this book and the page is shown in parentheses)

[10] Alisher Navoi. The seventh volume. Hayratul abror. Tashkent. Fan.1991. p.154-163.

[11] Sirojiddin Sayyid. Works. Volume III. Tashkent. Sharq, 2019. p. 558

[12] Sirojiddin Sayyid. Works. Volume III. Tashkent. Sharq, 2019. p.163.

[13] Jabborov N. Zamon. Mezon. Poetry. T. G. Gulom Printing House. 2015. p. 304 